\title{
Bernadetta Cich
}

Uniwersytet Papieski Jana Pawła II w Krakowie

\section{ETYKA INTYMNOŚCI W REPORTAŻU FILMOWYM - GRANICE LUB HORYZONTY WIDZENIA}

\begin{abstract}
Ethics of intimacy in film reportage - boundaries or horizons of vision. The expansion of the image code as a determinant of the material of messages in a mediated reality entails significant changes on many levels of digital society life. The speed of the image and strong persuasion of image messages, which results from the impression of the unquestionable authenticity, the bond with the truth interpreted by man as a reflection of facts or actual reality, becomes a tool in the sphere of business, media, politics and private life. They become a tool that persuades people to "buy", "watch", "receive", "choose", "attract". The aim of this article is to try to show some ethical aspects of the intimacy presented in the film reportage. The analyzes are an attempt to answer the question whether ethics constitutes limits or horizons of vision in presenting intimacy in a film reportage.
\end{abstract}

Etyka intymności w reportażu filmowym - granice lub horyzonty widzenia. Ekspansja kodu obrazowego jako determinującego tworzywa komunikatów w zmediatyzowanej rzeczywistości pociąga za sobą istotne zmiany na wielu płaszczyznach życia społeczeństwa cyfrowego. Szybkość działania obrazu i silna perswazja komunikatów obrazowych, która wynika z wrażenia niepodważalności autentyczności, więzi z prawdą interpretowanej przez człowieka jako odbicie faktów czy rzeczywistości faktycznej, staje się narzędziem w sferze biznesu, mediów, polityki czy życia prywatnego. Stają się one narzędziem, które przekonuje do „kupowania”, „oglądania”, „odbierania”, do „wybrania”, do „atrakcyjności”. Celem niniejszego artykułu jest próba pokazania niektórych etycznych aspektów intymności przedstawianej w reportażu filmowym. Analizy są próbą odpowiedzi na pytanie, czy etyka stanowi granice, czy też horyzonty widzenia w przestawianiu intymności $\mathrm{w}$ reportażu filmowym. 
Keywords ethics, intimacy, film reportage, image code, image, message

etyka, intymność, reportaż filmowy, kod obrazowy, obraz, komunikat

Ekspansja kodu obrazowego jako determinującego tworzywa komunikatów w zmediatyzowanej rzeczywistości pociąga za sobą istotne zmiany na wielu płaszczyznach życia społeczeństwa cyfrowego. Szybkość działania obrazu i silna perswazja komunikatów obrazowych, która wynika z wrażenia niepodważalności autentyczności, więzi z prawdą interpretowanej przez człowieka jako odbicie faktów czy rzeczywistości faktycznej, staje się narzędziem w sferze biznesu, mediów, polityki czy życia prywatnego. Komunikaty obrazowe stają się narzędziem, które przekonuje do „kupowania”, „oglądania”, „odbierania”, do „wybrania”, do „atrakcyjności”.

Ta przestrzeń to szybka, nieuchwytna gra obrazów, które pojawiają się i znikają, czasem w obniżonym stopniu świadomości „oglądania”, który charakteryzuje patrzącego odbiorcę. Rzeczywistość XXI wieku, można zaryzykować stwierdzenie, to „czas ekspozycji”. Ekspozycji „wszystkich” i „wszystkiego”, a im ekspozycja pośród innych ekspozycji jest bardziej przyciągająca, tym szanse przebicia się komunikatu są większe. Ten czynnik zdaje się być pierwszym kryterium w tworzeniu, mówiąc najogólniej przekazów medialnych. Paradoksalnie w tym wrażeniu autentyczności, odbioru faktów, świat wirtualny jest przestrzenią, którą twórcy komunikatów i jednocześnie ich odbiorcy nie łączą ze światem rzeczywistym w sferze etyki. Wydaje się, jakby świat wirtualny był „światem przedstawionym”, mówiąc językiem Romana Ingardena ${ }^{1}$, którego krańce zamykają się do ekranu komputera czy smartfonu. W „świecie przedstawionym” wszystko wolno, tylko wyobraźnia stawia granice. Zatem przestrzeń wirtualna zaczyna działać jak przestrzeń świata utworu literackiego na zasadzie praw rządzących fikcją. „Poplątany, wielomodalny, interaktywny tekst, w którym wszystko i wszyscy znajdują swoje miejsce - pisze Wiesława Woźniak - to nieprzerwana przestrzeń możliwego rozmywania kategorii etycznych. Mediosfera, która jawi się jako królestwo niezliczonych możliwości, stanowi również obszar niebezpieczeństw, poważnie zagrażający formowaniu wrażliwości moralnej podmiotu i jej aksjologicznym umocowaniu"2.

W tym kontekście ciekawe staje się umocowanie etyczne obrazów intymnych $\mathrm{w}$ reportażach filmowych, które z punktu widzenia warsztatów i kryterium tzw. "oglądalności” mogłyby zostać uznane za nieetyczne, godzące w ludzką godność, wpisujące się w epokę „ekspozycji wszystkiego". O znieczuleniu i zobojętnieniu poprzez reportażowe zdjęcia wyrażające okrucieństwo wojny pisała już Suzan Sontag, podejmując rozważania etyczne na temat ekspozycji bólu i cierpienia ${ }^{3}$. Pojęcie godności właśnie jest tu miernikiem etyczności przekazu. „Łatwiej ją czuć niż poznawać i opisywać. Zawiera ona w sobie takie treści, jak cześć, szacunek, dobra sława, dobre imię, poważanie, prestiż, honor, wartość człowieka itp. Człowiek jako osoba posiada

\footnotetext{
${ }^{1}$ Por. R. Ingarden, Szkice z filozofii literatury, Kraków 2000.

${ }^{2}$ W. Woźniak, Moralne dyskursy mediatyzacji, „Zeszyty Prasoznawcze” 2015 nr 1, s. 95.

${ }^{3}$ https://archiwum-obieg.u-jazdowski.pl/artmix/27823 (08.08.2019).
} 
godność, która określa jego osobową wartość, nieporównywalną z niczym innym. Dla jakiejkolwiek etyki komunikacji fundamentalne znaczenie ma to, czy i w jakim stopniu bierze ona pod uwagę ów konstytutywny i niezbywalny fundament godności ludzkiej”" - zauważa Michał Drożdż.

\section{Pojęcie int ymności}

W świecie ekspozycji granice tego, co w powszechnym rozumieniu intymne stają się nieostre. Ponadto trzeba zadać sobie pytanie o to, kto te granice stawia i kiedy to, co ujawnia obraz jest intymne. Czy jest to ten, który eksponuje, czy ten który odbiera obraz? A w kontekście reportażu filmowego, czy są to granice otwartości bohatera, Czy konieczność, jaką autor musi wypełnić chcąc tworzyć w określonym gatunku?

„Intymny” według słownika Kopalińskiego oznacza tyle, co ściśle osobisty, poufny, sekretny, bliski, zażyły ${ }^{5}$. W Słowniku języka polskiego pod red. Witolda Doroszewskiego wymieniane są trzy znaczenia tego pojęcia, z przewagą znaczeń o erotycznych konotacjach:

1. „bardzo osobisty charakter czegos',

2. „erotyczny, miłosny charakter czegoś,

3. „sprawa bardzo osobista, często o charakterze erotycznym”.

Robert Sternberg, amerykański psycholog i psychometra, profesor Uniwersytetu Cornella w „teorii miłosnego trójkąta”, intymność wymienia jako jedną ze składowych związku pośród namiętności i przywiązania oraz definiuje ją następująco: „Intymność: znajomość siebie samego oraz drugiej osoby. Pełne zaufanie co do tego kim ta druga strona jest, co robi i co czuje. Bliskość i troska o jej dobre samopoczucie. Potrzeba pojednania i wzajemnego wspierania się oraz zwierzania" ${ }^{6}$. Definicja otwiera nowy horyzont rozumienia etyki intymności. Byłaby to relacja między autorem, reportażystą a bohaterem reportażu. A skąd wynika ten kierunek myśli? Obrazy intymne przyciągają, są atrakcyjne z punktu widzenia warsztatu, zapewniają ,oglądalność”. Zadaniem reportażysty jest dotarcie do bohatera, najdalej, jak to możliwe, do jego wnętrza, do prawdy o nim i do jego świata. Reportażysta musi swojego bohatera otworzyć, żeby ujawnił mu swoją tajemnicę, którą ten odsłoni w przestrzeni medialnej, a więc wyeksponuje intymność bohatera. Takie myślenie o warsztacie reportażu, pozwala stworzyć najlepsze reportażowe dzieła. Reportażysta wkracza w świat swojego bohatera z kamerą i go rejestruje, a więc już na tym etapie przekracza granice intymności. Jednakże kiedy przekroczenie intymności i ekspozycja nie uwłaczają ludzkiej godności, nie poniżają człowieka, nie narażają na utratę dobrego imienia? Jakie jakości estetyczne pozwalają na otwieranie nowych horyzontów „etycznego widzenia”, „nieetycznych”, intymnych

${ }^{4}$ M. Drożdż, Osoba i media - personalistyczne uwarunkowania komunikacji, w: Nie lękajcie się. Jan Paweł II i media, red. A. Baczyński, M. Drożdż, Kraków 2011, s 36-37.

${ }^{5} \mathrm{https} / / /$ sjp.pwn.pl/sjp/intymnosc;2466780.html (06.07.2019).

${ }^{6}$ B. Wojciszke, Psychologia miłości. Namiętność, intymność, zaangażowanie, Gdańsk 2003, s. 58. 
obrazów, które bez granic kontekstowych uzyskałyby inne znaczenia? Wydaje się, że jesto to właśnie budowanie więzi $\mathrm{z}$ bohaterem i bohatera $\mathrm{z}$ odbiorcą oraz troska, która niewątpliwie jest wartością etyczną.

\section{REPORTAŻ FILMOWY - PROBLEM DEFINICJI}

Definicja reportażu filmowego nie jest jednoznaczna. To utwory na granicy filmu dokumentalnego i reportażu, rejestrujące pewien fragment rzeczywistości. Jednak nie chodzi tu o reportaż stworzony w technice filmowej w odróżnieniu od reportażu literackiego, ale o taką kompozycję i wykorzystane środki artystyczne, które zbliżają materiał dziennikarski do artystycznego filmu fabularnego, który staje się faktograficznym visual story. Cechą wyróżniającą może tu być możliwość odczytania przesłań uniwersalnych jako jakości estetycznych, które powstają w odpowiedniej kompozycji obrazu, muzyki i słowa, gdzie zestawianie tych warstw, sprawia, że na ich styku powstają nowe jakości estetyczne. Kategoria budowy bohatera, konstrukcji napięcia i dramaturgii odgrywa tu istotną rolę. Jednakże, co istotne, reportaż filmowy zawsze budowany jest na faktach. Fakty te mogą zostać poukładane tak, aby wyrażały wizję autora, zatem faktyczny świat przedstawiony jest również poddany pewnej kreacji. Te zabiegi sprawiają, że autor danego reportażu poprzez zestawienie obrazów zastanych, ujęć naturalnych, tworzy przekazy, które wyrażają prawdy metafizyczne. Otwiera się tu fenomenologiczny horyzont, gdzie docieramy za pomocą tego, co się jawi, do istoty rzeczy. „Fenomenologia klasyczna operowała przede wszystkim pierwszą funkcją języka: nazywała to, co widać” - pisze Tischner, analizując teksty Levinasa, i kontynuuje: „Wszelki język spełnia trzy funkcje, które są od siebie nieoddzielne: coś opisuje (np.: to jest drzewo), coś komunikuje (mówię Ci, że to jest drzewo), coś wyraża (Ach to jest drzewo). Mimo, że te trzy funkcje są nierozdzielne, to jednak w różnych sytuacjach są one różnie akcentowane”. I dodaje: „Fenomenologia opisu przechodzi w fenomenologię wyrazu”" Wydaje się, że film właśnie jako pewien kod przekazujący rzeczywistość ma zdolność omijania funkcji nazywania, żeby od razu wystąpić w funkcji wyrażania tego, co istotne i tego, co przejawia się w obrazach konkretnej rzeczywistości bohaterów i ich świata. Środkami wyrazu są tu metafory i symbole, a także kompozycja zderzenia ze sobą kontrastowych obrazów. Zatem rozumienie schematu komunikacyjnego musi oprzeć się tutaj na założeniu, że przekaz odbywa się na poziomie obrazów mentalnych, jakie wyłaniają się na podstawie konkretnych ujęć i ich zestawienia.

\footnotetext{
${ }^{7}$ J. Tischner, Myślenie wedlug wartości, Kraków 2000, s. 170.
} 


\section{ANALIZA WYBRANYCH REPORTAŻY}

A. Nad Ziemią (autor - Tomasz Bury) ${ }^{8}$. Bohaterką tu jest Bożena Jóźwiak. To emerytowana nauczycielka, która w pewnym momencie swojego życia zachorowała na stwardnienie rozsiane. Pierwszy kadr to drzwi, przez które zaglądamy do wnętrza mieszkania, gdzie w oddali bohaterka prowadzi rozmowę telefoniczną. Można z niej wywnioskować, że jest zmęczona swoją chorobą, mówi o eutanazji. Następnie w zbliżeniu profilu widzimy bohaterkę, która pali papierosa i w tzw. monologu wewnętrznym (wypowiedź pod obrazem) snuje refleksje na temat trudności swojego życia. Następnie w kadrach planowanych w detalach widzimy Bożenę Jóźwiak, która się ubiera, zapina spodnie (wystaje znaczna część bielizny), maluje się, czesze, ale we wszystkich tych czynnościach ręce są nieskoordynowane, więc każda podstawowa czynność - to duży trud. I dalej wychodzi do sklepu, musi o pomoc prosić przypadkowego klienta, wraca z zakupami i próbuje ugotować obiad. Widzimy jej stopy, dłonie, twarz, wszystko w detalach.

Szkielet schematu narracyjnego oparty jest na zasadzie realizacyjnej „dzień z życia” bohatera. Wszystkie te obrazy są intymne, bez upiększeń, myśli bohaterki - szczere. Bliskość kadrów pozwala na głębokie wejście w świat osoby chorej na stwardnienie rozsiane. Schemat narracji pozwala na wrażenie bycia $z$ bohaterką, współodczuwania. Sama Bożena Jóźwiak jest osobą pogodną, wszystkie czynności, które wykonuje świadczą o jej ogromnym pragnieniu życia w normalności. To daje obraz walki z chorobą. W trakcie reportażu nie poznajemy żadnych przyjaciół bohaterki. Jest samotna, wyizolowana. Nie ma scen spotkania, rozmowy. Ku zaskoczeniu widza w końcowej części reportażu bohaterka spełnia swoje marzenie i skacze ze spadochronem. Ujęcia z lotu na tle nieba, słońca, zbliżenia szczęśliwej twarzy bohaterki dają wrażenie zwycięstwa. Zatem konstrukcja materiału opiera się na dwóch wyrazistych obrazach:

- codzienność świata Bożeny jest trudna, pełna zmagań - to obraz ciemny, ciało bohaterki - to ciężkie „drewno”, które „trzyma, przykuwa do ziemi”, każde jej zmaganie - to oderwanie się, próba „latania”.

- spełnienie marzenie - jasne niebo, horyzont, radość, lot.

Na końcu bohaterka mówi: „modliłam się o zdrowie, a dostałam wolę walki”.

Zestawienie kontrastowe ty dwu obrazów tworzy przesłania uniwersalne: cierpieniu nie można się poddać; ciało ogranicza, ale dusza je może przekroczyć; w życiu trzeba walczyć do końca. Cały reportaż jest metaforą życia. Styl filmowania oparty jest na tzw. kamerze towarzyszącej. Autor przebywa kilka dni z bohaterką i wybiera te sytuacje, które dostatecznie ostro wyrażą założoną koncepcję, czyli trud życia. Czas filmu, czyli świata przedstawionego w schemacie "dzień z życia” nie równa się czasowi rzeczywistemu, ucieka od prawdy. Ale nie wpływa to na prawdę przekazu.

Widzowie reportażu bez dłuższego namysłu formułowali brzmienie przekazów uniwersalnych. Także twierdzili, że „oddychają” w drugiej części, kiedy widzą lot spadochronem, ponieważ pierwsza część ich przytłacza, czują ciężar losu bohaterki.

\footnotetext{
${ }^{8}$ https://krakow.tvp.pl/24865807/nad-ziemia (06.08.2019).
} 
Bez obrazów intymnych, które budziły empatię, współczucie, odczucie bezradności bohaterki nie zadziałałby obraz końcowy. Widz nie „dotknąłby” życia Bożeny Jóźwiak. Detale wyraziły tu emocje, stały się budulcem metafory. Samotność bohaterki, jej izolacja pozwala widzowi wejść w dialog z bohaterem i poznać chorobę. Zatem obrazy intymne mają tu wartość epistemologiczną. „Aby jednak mogło być spotkanie musi być jakaś samotność. Nie chodzi o czysto numeryczną odmienność człowieka od człowieka, jak rzeczy od rzeczy. Sens bytu jest warunkowany poprzez dialog z drugim"' - pisze Tischner. Ryzykując stwierdzenie można dodać, że doświadczanie świata i bólu bohatera, który przecież jest prawdziwy w prawdziwych sytuacjach i w prawdziwym świecie, odbitym w reportażu, jest przeżywaniem obecności z drugim. Według Tischnera: „Etyczność to sposób doświadczania i przeżywania obecności z drugim. Związki człowieka z człowiekiem nie są związkami ontologicznymi. A jednak bez tych związków żadna ontologia nie byłaby możliwa. [...] Są to związki typu transcendentalnego" ${ }^{10}$.

Zatem obrazy mentalne pozwalają na to doświadczenie, a komunikat reportażu pozwala na zbudowanie więzi pomiędzy widzem i bohaterem, które przekraczają formę fizyczną spotkania, a są ufundowane na współodczuwaniu.

B. Czasem śnię, że latam ${ }^{11}$ (autorka - Aneta Popiel-Machnicka). Podobny wymiar reprezentuje reportaż, którego bohaterką jest Weronika Frodyma - tancerka. Autorka swój reportaż realizowała pięć lat. Towarzyszy bohaterce z kamerą w najważniejszych momentach jej życia. Od zakończenia szkoły baletowej przez prestiżowy konkurs w Rosji, po sukces bycia w pierwszej obsadzie Narodowego Teatru w Berlinie i kontuzję kolana w dzień przed premierą, co w brutalny sposób zniweczyło marzenia bohaterki. Po wielu miesiącach terapii Weronika wraca do baletu. Obraz powrotu daje nadzieję na spełnienie marzenia. Bohaterka nie poddaje się, odradza się i poświęca swojej pasji.

W schemacie Czasem śnię, że latam oparte jest na linearnej historii fragmentu życia bohaterki. Zdarzenia następują po sobie w logicznym ciągu. Obraz jest tu warstwą informacyjną, co do następstwa faktów. Nie padła ani jedna wypowiedź do kamery, tzw. setka, nie występuje komentarz, ani monolog wewnętrzny. Obrazy intymne ukazują bohaterkę w momencie, kiedy płacze z bólu, ma krew na stopach, płacze z samotności, przerywa rozmowę z mamą, ponieważ złości się na swoją porażkę, jest na stole operacyjnym tuż przed operacją kolana, przewraca się z wyczerpania, przeżywa smutek z przegranego konkursu. Wszystkie ujęcia opierają się na bliskich planach np.: moment płaczu, to silne zbliżenie na twarz. Bohaterka w $90 \%$ materiału pojawia się w ujęciach wyizolowanych, bez przyjaciół i znajomych. To daje obraz olbrzymiej samotności. Ujęcia są naturalne i zastane. Dwa obrazy fabularyzowane, które nie pochodzą z rzeczywistego świata bohaterki potęgują metaforyczny przekaz reportażu filmowego. Są to wyścigi konne z efektem slow motion, gdzie jeden z koni upada. Obraz zestawiony z bardzo emocjonalną muzyką tworzą kontrast do kolejnego obrazu i efekt zaskoczenia widza. Drugi obraz to taniec bohaterki. Weronika w czarnej sukience w końcowej fazie tańca unosi się nad ziemią. Moment ten jest zestawiony z operacją, można odnieść wrażenie, że we śnie, w narkozie

\footnotetext{
9 J. Tischner, Myślenie według wartości, Kraków 2000, s. 170.

10 J. Tischner, Myślenie według wartości, dz. cyt., s. 170.

11 https://vod.tvp.pl/website/czasem-snie-ze-latam,30742026 (06.08.2019).
} 
spełnia swoje marzenie. Widzowie, którzy oglądali Czasem śnię, że latam twierdzili: „jak oglądałam/em, to mnie bolało" i tu dokładnie podawali momenty zbliżeń w intymnych obrazach, dodawali również: „,nie wiedziałem/am, że taka trudna jest praca tancerza”, „bardzo samotna jest Weronika”. Przekazy uniwersalne formułowane były jako myśli o przezwyciężaniu siebie, trudności, podnoszenia się z każdego upadku, po to, by iść dalej i walczyć o cel. Nikt nie chciał przerwać oglądania, sala była pogrążona w ciszy. Widzowie, jak w poprzednim reportażu, uważają, że doznali spotkania z bohaterem, weszli w jego świat, współodczuwali. Szczerość i naturalność intymnych obrazów sprawiła, że cały reportaż filmowy jest kontrobrazem do powszechnych przekonań o zawodzie tancerza. Materiał ujawnia prawdę, ujawniając to, co dla Weroniki bliskie, poufne, trudne emocjonalnie. Czasem śnię, że latam wzbudziło w Polsce dyskusję o sytuacji prawnej i socjalnej zawodowych tancerzy.

C. Niech żyje (autor Bernadeta Cich) ${ }^{12}$. To reportaż filmowy, opierający się na linii narracyjnej, którą zdefiniować można jako „opowieść na procesie”. Występuje tu bohater zbiorowy - śmiertelnie chore dzieci, które czekają na spełnienie swojego marzenia oraz dziewczynka, której marzenie się spełnia - zostaje tęczową księżniczką. Autorka uczestniczy $\mathrm{z}$ kamerą $\mathrm{w}$ procesie przygotowań do tęczowego balu.

Każde dziecko zostało przedstawione w ujęciach z przeważającą ilością planów bliskich - detali i zbliżeń. Mikroportrety pokazują dzieci podczas czynności, które lubią wykonywać - Krzyś gra w piłkę, Arek czyści motor, Paulina maluje, itp. Proces przygotowania do spełnienia marzenia obfituje $\mathrm{w}$ zbliżenia szycia sukienki, zabawek dziewczynki, które ma w pokoju. Każde dziecko opowiada o swoim marzeniu w monologu wewnętrznym przy okazji czynności, którą wykonuje. Portretom towarzyszom stopklatki, gdzie napis informuje, ile dziecko ma lat i na co jest chore. Po każdej stopklatce dziecko kończy opowieść. Po obejrzeniu widzowie twierdzili: „popłakałem się”, „tak mi smutno", „mają takie proste marzenia i taką straszną chorobę". Formułowane myśli uniwersalne brzmiały: „to pragnienie życia, w tym umieraniu”.

Detale i zabiegi artystyczne sprawiły, że widzowie weszli w świat dzieci. Ich emocje zostały mocno poruszone, co zmusiło oglądających do głębokich refleksji o życiu. Intymne obrazy spełniły tu funkcję otwarcia odbiorcy. Stanowią kontrobraz do wypowiedzi o marzeniach i dają poczucie bliskości.

\section{WNIOSKI -}

\section{GRANICE LUB HORYZONTY WIDZENIA}

Każda sytuacja, w której poznajemy, a w zasadzie zastajemy bohatera jest wybrana przez autora. Wybór determinują względy formalne gatunku i konieczność wysokiej jakości artystycznej oraz zgoda bohatera, który wyznacza granice dotarcia. Jednak zadaniem autora jest dotrzeć jak najbliżej do psychiki bohatera, a więc i jego intymności.

\footnotetext{
${ }^{12}$ https://krakow.tvp.pl/1468889/niech-zyje/! (06.08.2019).
} 
Zestawienie wybranych obrazów i wzajemnie wpływanie ich na siebie tworzą granice etycznego widzenia. Etyczne widzenie byłoby widzeniem nie sensacji, nie ,nieetycznych kadrów", czy widzeniem ciekawostki, do której jesteśmy zdystansowani, a widzeniem głębokiej intymności. Kamera obserwacyjna, która pozwala na trwanie $\mathrm{z}$ bohaterem i daje czas na wejście w jego świat, a więc i w kontekst wszystkich intymnych obrazów, sprawia, że to wyizolowanie bohatera, ograniczone detalami sytuacje otwierają horyzont etycznego widzenia, spotkania z człowiekiem, jego bólem i głębokiego spojrzenia na istotę życia. Ujęcia intymne, które w kompozycji obrazu pełnią funkcję wyrażania znaczeń, sensów i symboli, są visual storytellingiem, który ujawnia godność osoby w wymiarze metafor i symboli, jest nośnikiem myśli uniwersalnej. Takie widzenie prowadzi do empatii. Empatia to współodczuwanie. Nie ma tu miejsca na niegodne patrzenie, czyli na odebranie człowiekowi godności. W tym kontekście nie ma możliwości patrzenia rozrywkowego, jak na igrzysko, z dystansem. Mimo że spoglądamy na ujęcie z bliska, widząc szczegóły, patrzymy refleksyjnie.

Obowiązkiem etycznym autora jest wciągnięcie widza do świata bohatera. Budowanie konstrukcji i narracji, która nie jest oceniającym komentarzem życia bohatera, a kompozycją faktów w celu wydobycia jakości naddanych.

O etyce intymnych obrazów możemy mówić tu w następujących kontekstach:

- intencja autora w stosunku do obrazu dzieła. Tu granicą w prezentowaniu intymnych obrazów zdają się być szczerość autora, a co ciekawe - umiejętność w budowaniu wysoko jakościowego visual storytellingu,

- granice prawdy w kreacji świata opierającego się na faktach. Obrazy muszą być szczere, naturalne, zastane. Obserwacja $\mathrm{w}$ byciu $\mathrm{z}$ bohaterem sprawia, że przekaz jest głębszym obrazem świata bohatera. Dzielenie czasu z bohaterem jest wyrazem szacunku do niego samego i filmowanej rzeczywistości,

- odpowiedzialność autora wobec widza, czyli obrazy intymne umieszczone są w kompozycji filmu, która w przekazie pozwoli na etyczne ich widzenie, czyli w kontekście, w przestrzeni świata przedstawionego. Te same obrazy, np. w informacji, skrótowe i bez ograniczeń kontekstowych innych ujęć mógłyby zaistnieć w funkcji wywołania sensacji.

Ze względu na kryteria formalne budowa filmowa intymności zasadza się na następujących kryteriach:

- treść kadrów,

- detale - wyrażenie emocji,

- zbliżenia - bliskie kadrowanie pozwala uzyskać efekt bycia blisko bohatera,

- kamera towarzysząca - bycie z bohaterem na poziomie realizacji,

- budowanie postaci - szczere fakty tzw. sytuacje budowania filmowej intymności.

A zatem kryterium etyczne w eksponowaniu obrazów intymnych to funkcje tych obrazów w reportażu filmowym: budowanie bohatera, tworzywo przekazów uniwersalnych (w tym znaczeń symbolicznych i sensów), funkcja epistemologiczna - poznanie prawdy, funkcja budzenia współodczuwania, refleksji czy dyskusji. Najważniejsza jednak jest tu funkcja wyrażania, czyli docierania do istoty rzeczy i w konsekwencji - spotkania z człowiekiem. 


\section{LITERATURA}

Drożdż M., Osoba i media - personalistyczne uwarunkowania komunikacji, w: Nie lękajcie się. Jan Paweł II i media, red. A. Baczyński, M. Drożdż, Kraków 2011, s. 22-37.

Ingarden R., Szkice z filozofii literatury, Kraków 2000.

Tischner J., Myślenie według wartości, Kraków 2000.

Wojciszke B., Psychologia miłości. Namiętność, intymność, zaangażowanie, Gdańsk 2003, s. 58.

Woźniak W., Moralne dyskursy mediatyzacji, „Zeszyty Prasoznawcze” 58 (2015) nr 1, s. 89-101.

https://vod.tvp.pl/website/czasem-snie-ze-latam,30742026 (06.08.2019).

https://krakow.tvp.pl/1468889/niech-zyje/! (06.08.2019).

https://krakow.tvp.pl/24865807/nad-ziemia (06.08.2019).

https://archiwum-obieg.u-jazdowski.pl/artmix/27823 (08.08.2019).

https://sjp.pwn.pl/sjp/intymnosc;2466780.html (06.07.2019). 